https://doi.org/10.22364/hssl.28.2.06

\title{
EVALUATION OF THE SIGNIFICANCE OF THE RANKINGS OF HIGHER EDUCATION INSTITUTIONS
}

\section{Evija Rūsīte}

Mg. biol., Mg. sc. admin.

\begin{abstract}
More and more attention is being paid to university rankings - for student and financing attraction, and for research and graduate employment of the respective university - the reputation of universities is becoming more and more important. However, it is important to underline, that only approximately $1-3 \%$ of the world universities (200-500 universities) are represented in the most popular international rankings. Previous studies confirm that most international rankings focus predominantly on indicators related to the research function of universities. Therefore, the purpose of this study is to search for some possible solutions for more effective research work organisation at the universities and correct reflection of achieved results to raise their position in university rankings. The methods used in this study are scientific publication analysis, investigation of university ranking results with special attention to research organisation at the university and expert interviews and expert survey. Main findings: possible solutions for more effective research work organisation at the universities with aim to raise the position in different university ratings, are innovative encouragement and financial support of academic staff for active scientific publication creation, as well as practical and methodological support in the preparing of high level publication for young scientists. Also significant aspect is support of academic staff for international communication and extensive information on research results.
\end{abstract}

Keywords: Baltic States, university rankings, study and research organisation, higher education quality

\section{Introduction}

Demand for information about the quality and efficiency of higher education institutions grows, when the market of the higher education becomes more open and competitive, when the number of students and state funding to the higher education decreases and the influence of other factors. The role of measuring of the institutional quality of the higher education grows due to the interaction of many factors. An affordable way is the strengthening of the research aspect of the higher education institutions: both international and state financed research, and the participation in 
the research with local government and industry. Up to now there has not been conducted enough such research. There are many academic investigations with practically available suggestions for the facilitating of research and for the deeper study of this specific aspect. Formation of the ratings of higher education institutions is the way how to compare organisations for their parameters of activity. The role of ratings is to offer information about the quality of services in the form of measurable distinctions for the sponsors, clients, and policy makers. Ratings are influential. They foster the flow of doctoral students, elite scientists, and money of sponsors to the top institutions in the ratings. Ratings determine the reputation of the universities. They attract the interest of the society and change the behaviour of the universities and policy makers. The objectives of this study are to promote the place of higher education institutions in the international rankings by a study of higher education institutions, especially, by analysis of research performance indicators. Research methods used in this study includes analysis of scientific publications; comparison of results of leading Baltic universities in different international higher education institution rating systems in 2020, and analysing the role of performance indicators in the formation of rating position:

1) QS World University Rankings.

2) The Times Higher World University Ranking.

3) Academic Ranking of World Universities (ARWU or Shanghai Ranking).

\section{Theoretical findings}

Since the emergence of global rankings, universities have been unable to avoid national and international comparisons, and this has caused changes in the way universities function. The existence of rankings encourages universities to improve their performance. The question is, however, which type of actions they lead to. Researchers are investigating different approaches and suggesting active instruments for development of national higher education systems ${ }^{1}$. Striving to improve their position in the rankings, universities are strongly tempted to improve performance in those specific areas that are measured by the indicators used to prepare rankings ${ }^{2}$. The rankings are used to manage universities and take decisions

1 Lim, M.A., Øerberg, J.W. (2017). Active instruments: on the use of university rankings in developing national systems of higher education. Policy Reviews in Higher Education, 1(1), 91-108.

2 Rauhvargers A. (2011). Global university rankings and their impact. European University Association [on-line data] - [reference 21.09.2018.]. Accessible: www.eua.be. 
to make them as competitive as possible ${ }^{3}$ to prepare scholarly knowledge in the global market area. The rankings are distributed, used, discussed and criticised, but possible students, possible employers and other stakeholders are still using the university rankings ${ }^{4}$ and devoting a lot of attention suggesting to pay attention not only for teaching and research, but also to other aspects including race, gender, and cultural differences.

As it is highlighted in the "IREG Guidelines for Stakeholders of Academic Rankings"5, while academic rankings provide information about quality and performance and serve to promote transparency of information about higher education, they do not provide causal analysis of differences in performance among the systems, higher education institutions and their activity. Different rankings have different purposes, target different groups, select different indicators, and use different methodologies.

The methodology of rankings is a relatively new and important field of the study of higher education. Attention must be drawn to the context of the policy of ranking, the character and choice of indicators is very important ${ }^{6}$.

There is very important role for research output in analysing research profiles of higher education institutions - how research production is related to desired outcomes from higher education; is there evidence that research leads to economic gains for states and nations; to what extent is research used by the industry to develop new products and services that can benefit society; and are students better in terms of employment as a result of university research ${ }^{7}$.

Similarly, it is very essential to study the way in which research is organised at university, departmental and team levels ${ }^{8}$ - considering

3 Collyer, F. (2013). The production of scholarly knowledge in the global market arena: University ranking systems, prestige, and power. Critical Studies in Education, 54(3), 245-259.

4 Estera, A., Shahjahan, R.A. (2018). Globalizing whiteness? Visually re/presenting students in global university rankings websites, Discourse: Studies in the Cultural Politics of Education, Published online March 21, 2018, OI: 10.1080/01596306.2018.1453781.

5 IREG Observatory on Academic Ranking and Excellence (2018). IREG Guidelines for Stakeholders of Academic Rankings [on-line data] - [reference 12.08.2018.]. Accessible: www.ireg-observatory.org

6 Clarke M. (2002). Some Guidelines for Academic Quality Rankings. Higher Education in Europe, XXVii (4), 443-459.

7 Toutkoushian R. K., Webber K. (2011). Measuring the Research Performance of Postsecondary Institutions, Chapter 7. In: University Rankings: Theoretical Basis, Methodology, and Impacts on Global Higher Education. Ed. Shin J. Ch., Toutkoushian R. K., Teichler U. Springer, pp. 123-144.

8 Lansley, P. R., Luck, R., Lupton, S. (1995), The organization of construction research in British universities, Engineering, Construction and Architectural Management, 2(3), 179-195. 
the level of funding, the type of research projects and the resulting outputs, especially, how these benefit the industry.

There are many academic investigations with practically available suggestions for the facilitating of the research ${ }^{9}$. For example, W.Siwinski ${ }^{10}$ has emphasised in 2016 that the professional literature on quality in higher education shows that international rankings are doing well only in the area of science.

But there are researchers ${ }^{11}$ and politicians, as well as university administrators who raise questions on the necessity of university rankings and their applications. Critical views are discussed by researchers on aspects of joint university rankings - does one size fit to all ${ }^{12}$. Different aspects of researchers are important to make management decisions on different motivations for academic staff and especially management of the universities and national administrative institutions responsible for higher education development.

\section{Results of Empirical Research}

Methodologies of ratings and used indicators of the evaluation of research of universities are compared by use of criteria of indicators in higher education rankings.

Indicators must agree to such criteria:

- connected with aims and tasks of institution.

- direct (promptly describe what is being measured).

- objective (evident clear what is being measured).

- qualitative (as far as possible).

- comparable (results are similarly interpreted, when different study programmes or types of institutions are compared; institutionally, nationally, internationally etc.).

- practical (the count of indicators must be limited; data describing these indicators must be available).

9 Padilla-Meléndez, A., Garrido-Moreno, A. (2012), Open innovation in universities. International Journal of Entrepreneurial Behavior \& Research, 18(4), 417-439.

${ }^{10}$ Siwinski, W. (2016). What direction next for university rankings? 18 November 2016 University World News Global Edition, Issue 437; [on-line data] - [reference 20.09.2018.]. Accessible: http://www.universityworldnews.com/article.php?story= 20161114224439415.

${ }^{11}$ Soo, K. T. (2013). Does anyone use information from university rankings? Education Economics, 21(2), 176-190.

${ }^{12}$ Goglio, V. (2016). One size fits all? A different perspective on university rankings, Journal of Higher Education Policy and Management, 38(2), 212-226. 


\section{QS World University Rankings ${ }^{13}$}

Since the QS World University Rankings were first developed in 2004, they have expanded to rank more than 900 universities in 2020, with over 3,800 assessed.

- The top 400 universities are given individual ranking positions, and the rest are ranked in groups - starting from 501-510, up to 801+.

- Based on 6 performance indicators, the ranking assesses university performance across four areas: research, teaching, employability, and internationalisation:

- academic reputation $(40 \%)$

- employer reputation (10\%)

- student-to-faculty ratio $(20 \%)$

- citations per faculty (20\%)

- international faculty ratio $(5 \%)$

- international student ratio (5\%).

Table 1. Performance of Baltic Universities in QS World University Rankings (September 1, 2020)

\begin{tabular}{|c|c|c|c|c|c|c|c|c|}
\hline University & Rank & TOTAL & $\begin{array}{l}\text { Academic } \\
\text { reputation }\end{array}$ & $\begin{array}{l}\text { Employer } \\
\text { reputation }\end{array}$ & $\begin{array}{c}\text { Student- } \\
\text { to- } \\
\text { faculty } \\
\text { ratio } \\
\end{array}$ & $\begin{array}{l}\text { Citations } \\
\text { per } \\
\text { faculty }\end{array}$ & $\begin{array}{c}\text { Inter- } \\
\text { national } \\
\text { faculty } \\
\text { ratio } \\
\end{array}$ & $\begin{array}{c}\text { Inter- } \\
\text { national } \\
\text { student } \\
\text { ratio }\end{array}$ \\
\hline \multirow[t]{2}{*}{$\begin{array}{l}\text { University of } \\
\text { Tartu (EE) }\end{array}$} & $\begin{array}{c}321 \\
(2018)\end{array}$ & 32.8 & 20.4 & 21.6 & 82.7 & 18.9 & 22.4 & 20 \\
\hline & $\begin{array}{c}285 \\
(2020)\end{array}$ & 35 & 25.3 & 15.2 & 83.4 & 18.5 & 29.6 & 26 \\
\hline \multirow[t]{2}{*}{$\begin{array}{l}\text { Vilnius } \\
\text { University (LT) }\end{array}$} & $\begin{array}{c}488 \\
(2018)\end{array}$ & 24.1 & 16.9 & 31.8 & 60.2 & 6.1 & 11.7 & 6 \\
\hline & $\begin{array}{c}423 \\
(2020)\end{array}$ & 27 & 19.6 & 21.6 & 74.6 & 5.9 & 10.9 & 4.9 \\
\hline \multirow{2}{*}{$\begin{array}{l}\text { Vilnius } \\
\text { Gediminas } \\
\text { Technical } \\
\text { university (LT) }\end{array}$} & $\begin{array}{c}581-590 \\
(2018)\end{array}$ & - & - & 36 & 42.4 & - & - & 29.9 \\
\hline & $\begin{array}{c}651-700 \\
(2020) \\
\end{array}$ & - & - & 19.1 & 37.8 & - & - & 18.7 \\
\hline \multirow{2}{*}{$\begin{array}{l}\text { Tallin } \\
\text { University of } \\
\text { Technology } \\
\text { (EE) }\end{array}$} & $\begin{array}{c}\text { 601-650 } \\
(2018)\end{array}$ & - & - & 21.3 & 32.9 & - & 35 & 43.4 \\
\hline & $\begin{array}{c}651-700 \\
(2020) \\
\end{array}$ & - & - & - & 27 & - & 37.3 & 28 \\
\hline \multirow[t]{2}{*}{$\begin{array}{l}\text { Riga Technical } \\
\text { University (LV) }\end{array}$} & $\begin{array}{c}751-800 \\
(2018)\end{array}$ & - & - & 23.9 & 26.8 & - & 15.9 & 28.7 \\
\hline & $\begin{array}{c}701-750 \\
(2020) \\
\end{array}$ & - & - & 19.8 & 28.2 & - & 17 & 37.5 \\
\hline
\end{tabular}

${ }^{13}$ (http://www.topuniversities.com/qs-world-university-rankings; 02.05.2018). 


\begin{tabular}{|l|c|c|c|c|c|c|c|c|}
\hline \multicolumn{1}{|c|}{ University } & Rank & TOTAL & $\begin{array}{c}\text { Academic } \\
\text { reputation }\end{array}$ & $\begin{array}{c}\text { Employer } \\
\text { reputation }\end{array}$ & $\begin{array}{c}\text { Student- } \\
\text { to- } \\
\text { faculty } \\
\text { ratio }\end{array}$ & $\begin{array}{c}\text { Citations } \\
\text { per } \\
\text { faculty }\end{array}$ & $\begin{array}{c}\text { Inter- } \\
\text { national } \\
\text { faculty } \\
\text { ratio }\end{array}$ & $\begin{array}{c}\text { Inter- } \\
\text { national } \\
\text { student } \\
\text { ratio }\end{array}$ \\
\hline $\begin{array}{l}\text { Kaunas } \\
\text { University of } \\
\text { Technology } \\
\text { (LT) }\end{array}$ & $\begin{array}{c}751-800 \\
(2018) \\
801-1000 \\
(2020)\end{array}$ & - & - & 21.2 & 36.7 & - & - & - \\
\hline $\begin{array}{l}\text { Riga Stradiňš } \\
\text { University (LV) }\end{array}$ & $\begin{array}{c}801-1000 \\
(2020)\end{array}$ & - & - & - & - & - & - & 78.5 \\
\hline Tallin & $\begin{array}{c}801-1000 \\
(2020)\end{array}$ & - & - & - & - & - & 29.2 & 25.7 \\
\hline University (EE) & $\begin{array}{c}801-1000 \\
(2018) \\
\text { Lniversity of }\end{array}$ & - & - & - & 26.6 & - & - & - \\
\hline $\begin{array}{l}801-1000 \\
(2020)\end{array}$ & - & - & - & 18.3 & - & - & - \\
\hline $\begin{array}{l}\text { Vytautas (LV) } \\
\text { Magnus } \\
\text { university (LT) }\end{array}$ & $\begin{array}{c}801-1000 \\
(2018) \\
801-1000 \\
(2020)\end{array}$ & - & - & - & - & - & 28.1 & - \\
\hline
\end{tabular}

Source: Author's construction based on QS World University Rankings [reference 01.09.2020] http://www.topuniversities.com/qs-world-university-rankings

\section{The Times Higher World University Ranking ${ }^{14}$}

The Times Higher Education (THES) World University Rankings 2018-2020 list the 1500 top universities in the world, making it the biggest international league table to date.

- It is global university performance table to judge world class universities across all of their core missions - teaching, research, knowledge transfer and international outlook.

- THES ranking uses 13 carefully calibrated performance indicators.

- Ranking, which includes institutions from 79 countries, represents 5 per cent of the world's higher education institutions.

${ }^{14}$ (https://www.timeshighereducation.com/world-university-rankings; 01.09.2020). 
Table 2. The Times Higher Education World University Ranking (Qualitative indicators/ quantitative indicators 50:50\%)

\begin{tabular}{|l|l|c|}
\hline \multicolumn{1}{|c|}{ Field } & \multicolumn{1}{|c|}{ Indicator } & Ratio (\%) \\
\hline $\begin{array}{l}\text { 1. Teaching (the learning } \\
\text { environment) }\end{array}$ & & 30 \\
\hline & Reputation survey & 15 \\
\hline & Staff-to-student ratio & 4.5 \\
\hline & Doctorate-to-bachelor's ratio & 2.25 \\
\hline & Doctorates-awarded-to-academic-staff ratio & 6 \\
\hline $\begin{array}{l}\text { 2. Research (volume, income, } \\
\text { and reputation) }\end{array}$ & Institutional income & 2.25 \\
\hline & & 30 \\
\hline & Reputation survey & 18 \\
\hline & Research income & 6 \\
\hline 3. Citations (research influence) & Research productivity & 6 \\
\hline $\begin{array}{l}\text { 4. International outlook (staff, } \\
\text { students, and research }\end{array}$ & & 30 \\
\hline & International-to-domestic-student ratio & $\mathbf{7 . 5}$ \\
\hline & International-to-domestic-staff ratio & 2.5 \\
\hline & International collaboration & 2.5 \\
\hline $\begin{array}{l}\text { 5. Industry income (knowledge } \\
\text { transfer) }\end{array}$ & & 2.5 \\
\hline & Total & $\mathbf{1 0 0}$ \\
\hline
\end{tabular}

Source: The Times Higher Education Ranking [reference 20.09.2018.] https://www.timeshighereducation.com/world-university-rankings

Performance of universities of Baltic countries in THE or Times Higher Education World universities rankings are included in table 3.

Table 3. Performance of Baltic universities in the Times Higher Education World University Ranking

\begin{tabular}{|c|c|l|l|}
\hline $\begin{array}{c}\text { World rank } \\
\mathbf{2 0 1 9}\end{array}$ & $\begin{array}{c}\text { World rank } \\
\mathbf{2 0 2 0}\end{array}$ & \multicolumn{1}{|c|}{ University } & Country \\
\hline $301-350$ & $251-300$ & University of Tartu & Estonia \\
\hline $801+$ & $601-800$ & University of Latvia & Latvia \\
\hline $601-800$ & $801-1000$ & Tallin University of Technology & Estonia \\
\hline $601-800$ & $801-1000$ & Vilnius University & Lithuania \\
\hline- & $801-1000$ & Tallin University & Estonia \\
\hline- & $801-1000$ & Vilnius Gediminas Technical university & Lithuania \\
\hline $801+$ & $1001+$ & Kaunas University of Technology & Lithuania \\
\hline
\end{tabular}




\begin{tabular}{|c|c|l|l|}
\hline $\begin{array}{c}\text { World rank } \\
\mathbf{2 0 1 9}\end{array}$ & $\begin{array}{c}\text { World rank } \\
\mathbf{2 0 2 0}\end{array}$ & \multicolumn{1}{|c|}{ University } & Country \\
\hline $801+$ & $1001+$ & Riga Technical University & Latvia \\
\hline- & $1001+$ & Latvia University of Life Sciences and Technologies & Latvia \\
\hline- & $1001+$ & Vytautas Magnus university & Lithuania \\
\hline
\end{tabular}

Source: Author's construction based on THES ranking [reference 01.09.2020.] https://www. timeshighereducation.com/world-university-rankings

\section{Academic Ranking of World Universities (ARWU or Shanghai Ranking)}

The Academic Ranking of World Universities (ARWU) was first published in 2003 by the Center for World-Class Universities of Shanghai Jiao Tong University, China, and updated on an annual basis.

- ARWU uses 6 objective indicators to rank world universities, including the number of alumni and staff winning Nobel Prizes and Fields Medals, number of highly cited researchers selected by Thomson Reuters, number of articles published in journals of Nature and Science, number of articles indexed in Science Citation Index, and per capita performance of a university.

- More than 1200 universities are actually ranked by ARWU every year and the best 500 are published.

Table 4. Indicators and Weights for ARWU in Academic Ranking of World Universities (ARWU or Shanghai Ranking)

\begin{tabular}{|l|l|c|c|}
\hline \multicolumn{1}{|c|}{ Criteria } & \multicolumn{1}{|c|}{ Indicator } & Code & Weight (\%) \\
\hline \multirow{2}{*}{ Quality of Education } & $\begin{array}{l}\text { Alumni of an institution winning Nobel } \\
\text { Prizes and Fields Medals }\end{array}$ & Alumni & 10 \\
\hline \multirow{2}{*}{ Research Output } & $\begin{array}{l}\text { Staff of an institution winning Nobel } \\
\text { Prizes and Fields Medals }\end{array}$ & Award & 20 \\
\cline { 2 - 4 } & $\begin{array}{l}\text { Highly cited researchers in 21 broad } \\
\text { subject categories }\end{array}$ & HiCi & 20 \\
\hline & $\begin{array}{l}\text { Papers published in Nature and Science } \\
\text { expanded and Social Science Citation } \\
\text { Index }\end{array}$ & SCI & 20 \\
\hline Per Capita Performance & $\begin{array}{l}\text { Per capita academic performance of an } \\
\text { institution }\end{array}$ & Size & 10 \\
\hline Total & & & 100 \\
\hline
\end{tabular}

Source: Author's construction based on Academic Rankings of World Universities (ARWU) [reference 01.09.2020.] http://www.shanghairanking.com 
From universities in Baltic countries there is represented only University of Tartu having good results in international university rankings.

Table 5. Performance of Baltic Universities in Academic Ranking of World Universities (ARWU ranking or Shanghai Ranking 2016-2020)

\begin{tabular}{|c|c|c|c|c|}
\hline World rank & University & National rank & Total score & Score of alumni \\
\hline $401-500(2020)$ & $\begin{array}{c}\text { University of Tartu } \\
\text { (Estonia) }\end{array}$ & 1 & - & 0.0 \\
$301-400(2019)$ & & & & \\
$301-400(2018)$ & & & \\
$401-400(2017)$ & & & \\
\hline
\end{tabular}

Source: Author's construction based on ARWU [reference 01.09.2020.] http://www. shanghairanking.com

Rankings of higher education institutions indicate that the universities from Baltic countries have reached good results, but still a lot has to be done and universities from Latvia and Lithuania can learn from the experience from University of Tartu on considering management decisions for better performance in international university rankings.

\section{Conclusions and proposals}

- None of world popular approaches and methodologies of the evaluation and comparing of higher education institutions are absolutely objective.

- Different methodologies are used in the international rankings; however the evaluation of the research activity has significant proportion in all of them.

- Different indicators of research activity are used, but more significant are:

- number of publications in respectable journals / per academic staff / in citation data bases.

- index of citation.

- number of highly cited researchers.

- international research awards.

- number of doctoral degrees conferred.

- income from research.

- productivity of research.

- income from industry (transfer of knowledge and technology) etc.

Acquired findings indicate, that the results of research activity of universities have important role in the international ratings of higher education institutions and the improvement of these results facilitates the place of higher education institution in the ratings, thus fortifying, 
to which aspects of the strengthening of research activity must be drawn special role and attention in the missions and strategies of higher education institutions.

\section{REFERENCES}

Clarke, M. (2002). Some Guidelines for Academic Quality Rankings. Higher Education in Europe, 2002, Vol. XXVii(4), 443-458.

Collyer, F. (2013). The production of scholarly knowledge in the global market arena: University ranking systems, prestige, and power. Critical Studies in Education, 54(3), 245-259.

Estera, A., Shahjahan, R. A. (2018). Globalizing whiteness? Visually re/presenting students in global university rankings websites, Discourse: Studies in the Cultural Politics of Education, Published online March 21, 2018, OI: 10.1080/ 01596306.2018.1453781.

Goglio, V. (2016). One size fits all? A different perspective on university rankings, Journal of Higher Education Policy and Management, 38(2), 212-226.

IREG Guidelines for Stakeholders of Academic Rankings [on-line data] - [reference 21.09.2018.]. Accessible: www.ireg-observatory.org.

Lansley, P. R., Luck, R., Lupton, S. (1995). The organization of construction research in British universities, Engineering, Construction and Architectural Management, 2(3), 179-195.

Lim, M. A., Øerberg, J. W. (2017). Active instruments: on the use of university rankings in developing national systems of higher education. Policy Reviews in Higher Education, 1(1), 91-108.

Padilla-Meléndez, A., Garrido-Moreno, A. (2012), Open innovation in universities, International Journal of Entrepreneurial Behavior \& Research, 18(4), 417-439.

Rauhvargers, A. (2011). Global university rankings and their impact. European University Association [on-line data] - [reference 02.09.2018.]. Accessible: www. eua.be.

Siwinski, W. (2016). What direction next for university rankings? 18 November 2016 University World News Global Edition, Issue 437; [on-line data] - [reference 20.09.2018.]. Accessible: http://www.universityworldnews.com/article.php?story= 20161114224439415.

Soo, K. T. (2013). Does anyone use information from university rankings?, Education Economics, 21(2), 176-190.

Toutkoushian, R. K., Webber, K. (2011). Measuring the Research Performance of Postsecondary Institutions, Chapter 7. In: University Rankings: Theoretical Basis, Methodology, and Impacts on Global Higher Education. Ed. Shin, J. Ch., Toutkoushian, R. K., Teichler, U. Springer, pp. 123-144. 